\title{
Original papers
}

\section{Cardiac indexes, cardiac damage biomarkers and energy expenditure in professional cyclists during the Giro d'Italia 3-weeks stage race}

\author{
Roberto Corsetti ${ }^{1}$, Giovanni Lombardi2* ${ }^{2}$ Alessandra Barassi ${ }^{3}$, Patrizia Lanteri², Alessandra Colombini², \\ Gianvico Melzi D'Eril ${ }^{3}$, Giuseppe Banfi2,4 \\ ${ }^{1}$ Liquigas-Cannondale Pro-cycling Team, Medical Board, Faenza, Italia \\ ${ }^{2}$ I.R.C.C.S. Istituto Ortopedico Galeazzi, Milano, Italia \\ ${ }^{3}$ Dipartimento di Medicina, Chirurgia e Odontoiatria, University of Milano, Milano, Italia \\ ${ }^{4}$ Chair of Clinical Biochemistry, School of Medicine University of Milano, Milano, Italia \\ *Corresponding author: giovanni.lombardi@grupposandonato.it
}

\begin{abstract}
Introduction: The study of cardiac response to strenuous and continuous exercise is crucial to understanding the physiology of endurance. N-terminal proB-type natriuretic peptide (NT-proBNP) is a potential marker for monitoring myocardial wall stress, and troponins (TnT and Tnl) are widely used in the diagnosis of cardiac ischemia and infarction. Strenuous exercise may generate transitory ischemia, myocardial stress, and diastolic left ventricular dysfunction, inducing the increased production of both these biomarkers. We measured changes in NT-proBNP and TnT in elite cyclists during a 3-week stage race, a model of strenuous exercise.
\end{abstract}

Materials and methods: The study population was 9 professional cyclists participating in the 2011 Giro d'Italia. Pre-analytical and analytical phases scrupulously followed official recommendations. Anthropometric data, net energy expenditure and cardiac indexes (rate, diastolic and systolic blood pressure) were recorded. Blood samples were drawn pre-race (day -1) and at days 12 and 22; NT-proBNP and highly sensitive-troponin (Hs$\mathrm{TnT}$ ) concentrations were assayed and corrected for plasma volume changes.

Results: Body-mass index decreased and energy expenditure increased by 52\% during the race. NT-proBNP concentrations increased [day -1: 23.52 $\mathrm{ng} / \mathrm{L}$ (9.67-34.33); day 12: $63.46 \mathrm{ng} / \mathrm{L}$ (22.15-93.31); $\mathrm{P}=0.039 ;$ day 22: $89.26 \mathrm{ng} / \mathrm{L}(34.66-129.78)$ vs. day $-1 ; \mathrm{P}<0.001$ ] and correlated with heart rate $(r=-0.51 ; P=0.006)$, systolic pressure $(r=0.39 ; P=0.046)$ and energy expenditure $(r=0.70 ; P<0.001)$. TnT concentrations did not vary, but a widened TnT amplitude distribution was observed.

Conclusions: Increases in NT-proBNP correlated with higher energy expenditure over a 3-week cycling stage race, possibly indicating myocardial stress.

Key words: amino-terminal pro-brain natriuretic peptide; troponin T; physical endurance; energy expenditure

\section{Introduction}

The 76 amminoacid N-terminal proB-type natriuretic peptide (NT-proBNP) has been proposed as a marker for evaluating and monitoring cardiac abnormalities characterized by myocardial wall stress (1). Strenuous exercise may generate transitory ischemia, myocardial stress, and diastolic left ventricular dysfunction, resulting in increased production of NT-proBNP suggestive of incipient heart disease.
Increased NT-proBNP levels after physical exercise in endurance athletes $(2,3)$ and after heavy physical exercise in professional athletes has been described $(4,5)$. In appropriately trained athletes, the production of this peptide is lower at rest and exercise-induced increases remain below abnormal limits $(6,7)$. NT-proBNP concentrations in rugby players, for example, were not substantially affected by post-training recovery (passive, active recov- 
ery followed by cold-water immersion, cold-water immersion followed by active recovery) (6).

The rationale for the use of NT-proBNP, instead of mature BNP, as marker for cardiac dysfunction resides in their different half-life (90-120 versus 18 min) (8). The finding that NT-proBNP, but not intact BNP is augmented after endurance sport performance (9) is a consequence of the different life spans of the molecules.

Exercise-induced production of NT-proBNP needs to be distinguished from abnormal increases due to heart damage. NT-proBNP is a reliable diagnostic and prognostic marker in patients with suspected heart failure. Chronic elevations, along with those of other natriuretic peptides, aid in identifying and monitoring cardiac dysfunction. Differently, exercise-induced NT-proBNP changes, particularly in well-trained professional athletes, reflect an acute response to altered hemodynamics, regional wall-motion abnormalities, and exercise-induced transitory myocardial wall ischemia (10). Furthermore, exercise-induced NT-proBNP production in such athletes very likely stems from a cytoprotective mechanism $(2,11)$.

The mechanism underlying its release has not been elucidated. Systemic inflammation following strenuous exercise may stimulate the release of NT-proBNP into the circulation (11).

Cardiac damage was inferred from high NT-proBNP concentrations measured in 60 non-professional athletes after a marathon (7): $60 \%$ of the recreational runners had increased troponin $\mathrm{T}(\mathrm{TnT})$ and NT-proBNP levels; left ventricular size and ejection fraction were unchanged but left ventricular compliance was reduced; changes in biochemical signs of cardiac damage were more pronounced in the runners who had trained at low training workloads. The study results serve as a reminder that appropriate preparation is mandatory to protect athletes against potentially harmful elevation of cardiac biomarkers and the risk of cardiac dysfunction associated with endurance performance (7).

Troponins ( $\mathrm{T}$ and $\mathrm{I})$ are commonly used diagnostic markers for cardiac ischemia and infarction. Their relevance for sports medicine was highlighted in a recently published critical review of studies on in- creased troponin levels after prolonged strenuous physical activity (12). With the advent of assays with high analytical sensitivity, also known as highly sensitive troponin (Hs-Tns) tests, the negative predictive value of troponin testing has improved, but its clinical specificity has substantially decreased (13).

Evaluating Tns release after prolonged strenuous exercise poses a challenging problem for clinical chemistry. Several hypotheses have sought to explain the release of cardiac proteins, focusing mainly on increased membrane permeability and leakage of the unbound cytosolic pool, which comprises only a small part of the total pool of cardiac Tns (14). Tns loss due to higher membrane permeability and the formation of "blebs" (15), i.e., membrane evaginations possibly providing the pathway for protein release, could explain the coexistence of serum Tns in a disease state and in the absence of myocardial dysfunction (16). Transient ischemia, which may occur during exercise, would not normally be sufficient to induce irreversible membrane injury: the blebs are reabsorbed or released into the circulation, where low and shortlasting amounts of Tns detectable with the new highly sensitive assays can be measured. In permanent damage, due to lack of reoxygenation, the blebs collapse and are not shed into circulation; subsequently, high amounts of Tns are released, with myocell necrosis and lysis, a feature typical of myocardial infarction.

Numerous studies utilizing last-generation Tns assays have been performed on athletes: runners (21 studies); triathletes (one study); and basketball players (one study) (12). Only one study involved 91 non-professional cyclists participating in a cycle-touring event (206 km) (17); in $43 \%$ of the cyclists, Tnl exceeded the upper reference limit (URL) already at $20 \mathrm{~min}$ post-exercise.

Biomarkers for cardiac overload and damage have been studied in single, one-day, and ultraendurance events. A study published in 1996 and involving endurance athletes in a prolonged stage race used a now outmoded TnT assay which was affected by interference from skeletal muscle proteins. However, cardiac TnT (cTnT) was found in the serum of only 5 athletes, repeatedly in some cases, 
but always below the cut-off values for myocardial ischemia. On the basis of the behaviour of creatine kinase isoenzyme MB and, above all, of cTnT, it was concluded that heavy-endurance exercise repeated daily for 22 days was unable to induce permanent heart damage by acute myocardial injury in top athletes (18).

The study of biochemical parameters of cardiac damage is crucial for defining their behaviour after endurance, strenuous and continuous exercise and to avoid misinterpreting elevated serum levels. Equally important is setting cut-off values in endurance athletes to avert misrecognition of signs of myocardial overload or frank pathology.

Evaluating cardiac response is essential for improving our understanding of the physiology of endurance. Here we report on the changes in NT-proBNP and $\mathrm{Hs}-\mathrm{TnT}$ in relation to energy expenditure in professional athletes during a 3-week staged cycling race, a universally accepted model of strenuous exercise.

\section{Materials and methods}

\section{Subjects}

This prospective, non-comparative interventional study involved 9 professional cyclists from the Liquigas-Cannondale professional cycling team. All subjects had participated in the 2011 Giro d'Italia and were followed during the duration of the race from 8 through 29 May 2011.

The mean completion time for the cyclists was 86:47:29 h (range, 84:12:10-88:15:51 h) with a mean speed of $35.7 \mathrm{~km} / \mathrm{h}$. The median age was 26 years (range, 24-33). Height, weight and body-mass index (BMI) were measured the morning before the start of each stage under fasting and rest condi- tions (Table 1). Diet was strictly controlled by team physicians.

Three subjects received non-steroidal anti-inflammatory drugs (NSAIDs) and antibiotics for an upper respiratory tract infection for 5 days during the first week (one case) and during the second week (two cases). The 2011 Giro d'Italia was a "no-needle" race in which therapies and drugs were permitted only for evident illness.

Blood drawings were performed on the day before the start (day -1), on the $12^{\text {th }}$ day (day 12), and on the final day of the race (day 22) (Figure 1).

The total net energy expenditure (kcal) for each stage was derived from the developed power measured with a power sensor (PowerMeter ${ }^{\mathrm{TM}}$, SRM $\mathrm{GmbH}$, Jülich, Germany) incorporated into the bike pedal (sensitivity $\pm 2 \%$ ). The measures taken during the race are relative to the day before the blood drawings to allow the determination of correlation.

The study design and protocol were approved by the reference ethical committee (ASL Città di Milano); informed consent was obtained from all subjects before the beginning of the study.

\section{Methods}

\section{Blood drawings}

Adherence to pre-analytical recommendations was strictly observed to prevent factors from inadvertently affecting the analytical data. The Union Cycliste Internationale (UCI) and World Anti-Doping Agency (WADA) rules for collection and transport of specimens were followed $(19,20)$.

Blood drawing was performed between $08.00 \mathrm{hrs}$ and $10.00 \mathrm{hrs}$ after overnight fasting with subjects resting in bed for 10 minutes after awaking.

TABLE 1. Anthropometrical measurements recorded at the three time-points. Measurements are expressed as median and distribution range $\left(5^{\text {th }}-95^{\text {th }}\right.$ percentile). The different superscripts denote statistical significance at $\mathrm{P}<0.05$.

\begin{tabular}{lcccc}
\hline Parameter & day -1 & day 12 & day 22 & P value \\
\hline Height $(\mathrm{m})$ & $1.83(1.74-1.86)$ & $/$ & $/$ & $/$ \\
Weight $(\mathrm{kg})$ & $67.0(63.1-75.9) \S$ & $66.5(63.7-76.0) \S$ & $65.5(61.6-73.4)^{*}$ & 0.023 \\
BMI $\left(\mathrm{kg} / \mathrm{m}^{2}\right)$ & $20.9(19.3-22.5) \S$ & $20.8(19.5-22.4) \S^{*}$ & $20.9(19.0-21.5)^{*}$ & 0.019 \\
\hline
\end{tabular}




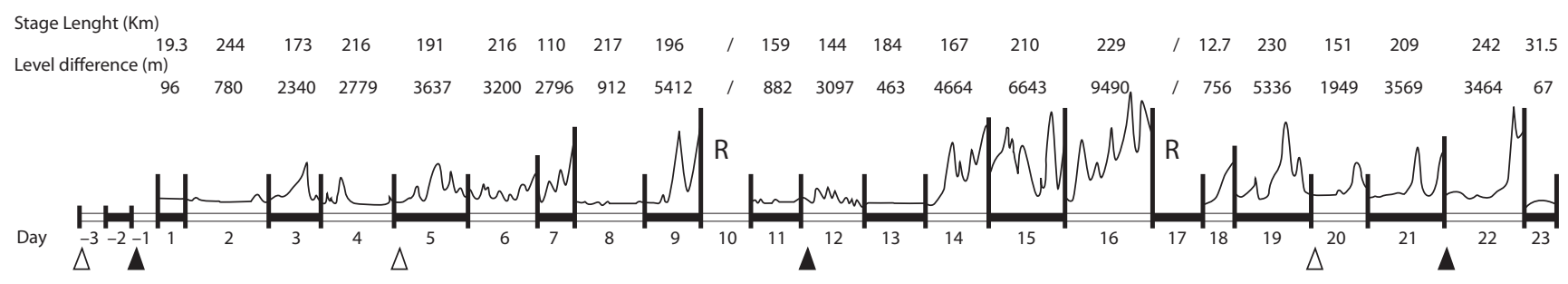

FigurE 1. Race features. The diagram illustrates length $(\mathrm{km})$ and difference in elevation $(\mathrm{m})$ of each stage, day of each stage, days of rest $(R)$, day of blood sampling for this study $(\mathbf{\Lambda})$, and day of blood sampling for official anti-doping testing $(\Delta)$.

Evacuated tubes (BD Vacutainer Systems, BectonDickinson, Franklin Lakes, NJ, USA) were used for the haematological tests (BD K ${ }_{2}$ EDTA $3.5 \mathrm{~mL}$ tubes); $7 \mathrm{~mL}$ plain tubes (BD SSTII Advance) were used for clinical chemistry tests. Immediately after blood drawing, the tubes were inverted 10 times and stored in a sealed box at $4{ }^{\circ} \mathrm{C}$. Controlled temperature was assured during transport: a specific tag (Libero Ti1, Elpro, Buchs, Switzerland) was used for temperature measurement and recording. The samples were transported by car or train and car: the time elapsed between blood drawing and arrival at the laboratory was 1.30 hrs on day $-1,7.50$ hrs on day 12 , and 1.30 hrs on day 22 . After arrival at laboratory, the $\mathrm{K}_{2}$ EDTA-anticoagulated blood was homogenized for a minimum of 15 min with an appropriate mixer prior to analysis, as recommended by the UCI Blood Analytical Protocol (January 2009) and the Athlete Biological Passport Operating Guidelines WADA (January 2010) $(19,20)$. Plain tubes were immediately centrifuged $1300 \times \mathrm{g}$ at $4{ }^{\circ} \mathrm{C}$ for $10 \mathrm{~min}$ and the serum was stored at -80 ${ }^{\circ} \mathrm{C}$ until analysis.

\section{Cardiac indexes}

Resting heart rate and diastolic and systolic pressure were measured in the morning with the subjects resting in bed immediately after awakening. The measurements were performed in duplicate at the wrist with an OMRON R3 ${ }^{\mathrm{TM}}$ (Omron Healthcare Co. Ltd, Kyoto, Japan).

\section{Calculation of plasma volume changes}

Repeated measurement of blood parameters in humans during and after physical activity is influenced by changes in plasma volume (21). The per- centage variation in plasma volume ( $\triangle \mathrm{PV} \%)$ at consecutive time-points was calculated according to the formula (21):

$$
\begin{gathered}
\Delta \mathrm{PV} \%=100 \times\left[\left(\mathrm{Hb}_{\text {pre }} / \mathrm{Hb}_{\text {post }}\right) \times\left(1-\mathrm{Ht}_{\text {pos } \mathrm{t}} / 100\right) /\right. \\
\left.\left(1-\mathrm{Ht}_{\text {pre }} / 100\right)\right]-100 ;
\end{gathered}
$$

where $\mathrm{Hb}_{\text {pre }}$ and $\mathrm{Hb}_{\text {post }}$ are the pre- and the postintervention haemoglobin $(\mathrm{Hb})$ concentration, respectively, and $\mathrm{Ht}_{\text {pre }}$ and $\mathrm{Ht}_{\text {post }}$ are the pre- and the post-intervention haematocrit $(\mathrm{Ht})$ percentages, respectively.

The analyte concentrations measured at days 12 and 22 were corrected for relative changes in PV\% using the following equation:

\section{Corrected values $=$ uncorrected values $\mathrm{x}$} $[100-\Delta \mathrm{PV}(\%)] / 100$

\section{Measurement of cardiac biomarkers}

NT-proBNP and Hs-TnT levels were measured on a Roche Modular Analytics EVO analyzer (Roche Diagnostics, Lewes, Sussex, UK) with Elecsys ${ }^{\circledR}$ proB$\mathrm{NP}$ and Elecsys ${ }^{\circledR} \mathrm{Hs}-\mathrm{TnT}$, respectively. Both methods are based on sandwich immunodetection.

Serum NT-proBNP measurement had an analytical range of 5-35,000 ng/L, an inter-assay coefficient of variation (CV) of 0.7 to $1.6 \%$, and an intra-assay CV of 5.3 to $6.6 \%$. Serum Hs-TnT measurement had an inter-assay $\mathrm{CV}$ of $8 \%$ at $10 \mathrm{ng} / \mathrm{L}$ and $2.5 \%$ at 100 $\mathrm{ng} / \mathrm{L}$, and an intra-assay CV of $5 \%$ at $10 \mathrm{ng} / \mathrm{L}$ and $1 \%$ at $100 \mathrm{ng} / \mathrm{L}$. The analytical range of this assay is 2 to $10,000 \mathrm{ng} / \mathrm{L}$.

\section{Statistical analysis}

Statistical analysis was performed using GraphPad Prism ${ }^{\circledR}$ ver. 5.0 (GraphPad Software, La Jolla, CA, 
USA). All values in the descriptive analysis are expressed as median and distribution range $\left(5^{\text {th }}-95^{\text {th }}\right.$ percentile). Friedeman's test was used to compare values over time with Dunn's post-hoc test. The widening in TnT amplitude distribution was evaluated by the Levene's test. Correlation analysis between the measured parameters was performed using the two-tailed Spearman's rank correlation test. Significance was set at $\mathrm{P}<0.05$.

\section{Results}

\section{Anthropometrical measurements}

There was a significant decrease in both body weight and BMI during the race. At day 22, weight significantly differed from that measured at day -1 and day 12 , while BMI was significantly lower than at day -1 (Table 1).

Except for the baseline values, the energy expenditure was calculated for the days before the blood drawings to evaluate a possible relationship between the previous metabolic effort and the consequent physiological response.

A significant difference in net energy expenditure between the three time-points was seen. Energy expenditure increased by about $21 \%$ between the rest values and day $12(P=0.039), 39 \%$ between days 12 and $22(P=0.008)$, and $52 \%$ between days -1 and $22(P<0.001)$ (Figure 2). The increase observed at day 21 was related to the differences in topographic elevation during the second half of the race: the first part of the race was composed of 5 plain stages, 3 middle-high mountain stages, and 2 high-mountain stages (total difference in elevation $21,952 \mathrm{~m}$ ); the second part was composed of 3 plain stages, 3 middle-high mountain stages, and 5 high-mountain stages (total difference in elevation 40,313 m) (Figure 1).

\section{Cardiac indexes}

Resting heart rate and systolic and diastolic blood pressure values remained unchanged during the race.

\section{Changes in plasma volume}

As calculated with the Dill \& Costill formula (21), no significant changes in plasma volume were ob-

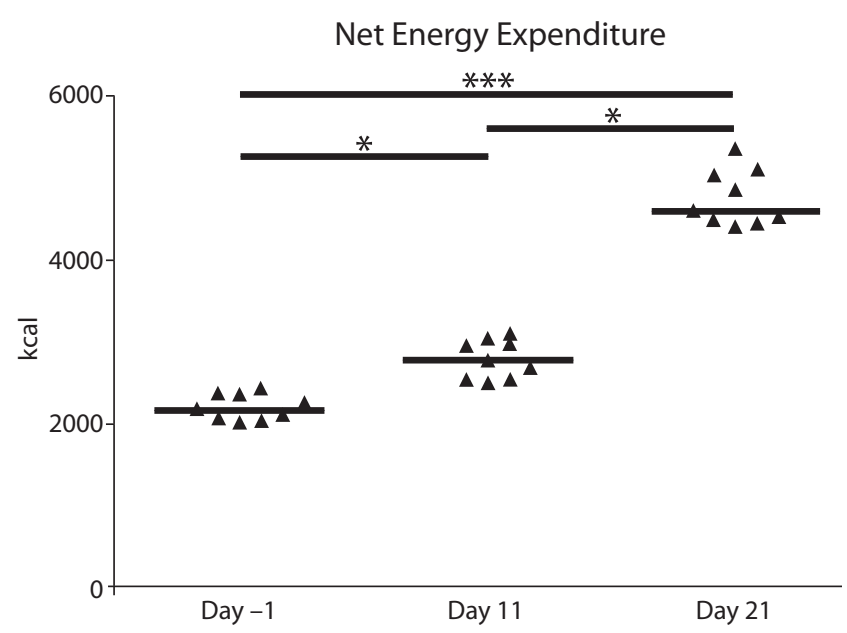

Figure 2. Net energy expenditure during the race. The graph shows the total net energy expenditure at baseline (day -1) and the days before the following blood drawings (day 11 and day 21). Triangles denote the individual concentrations of the analytes; the solid lines denote the median; ${ }^{*} \mathrm{P}<0.05$, ${ }^{* *}$ : $\mathrm{P}<$ 0.0001

served during the race. Descriptively, the median PV\% increased in the first part of the race (day -1 to day 12$)$ by $1.55 \%(0.45-3.34)$ and decreased in the second part by $-0.72 \%(-1.95-0.80)$ (day 12 to day 22). The net increase in PV between days -1 and 22 was $0.99 \%(-0.86-2.34)$.

The changes in PV paralleled those in both [Hb] and $\mathrm{Ht}$, which did show significant variations during the race. $[\mathrm{Hb}]$ decreased from day $-1[146 \mathrm{~g} / \mathrm{L}$ (137-154)] to day 12 [131 g/L (127-142)] $(P=0.031)$ but did not significantly increase between days 12 and 22 [133 g/L (127-150)]; the net variation over baseline to the end of the race was significant $(P=$ 0.004).

The same trend was observed for $\mathrm{Ht}$ : a decrease from day -1 [42.7\% (40.8-44.8)] to day 12 [39.2\% (37.8-42.1); $P=0.009]$, followed by an insignificant increase from day 12 to day 22 [39.8\% (37.8-44.0)]; the net variation over baseline to the end of the race was significant $(P=0.010)$.

\section{Biomarker analysis}

Serum NT-proBNP increased significantly over baseline from $23.52 \mathrm{ng} / \mathrm{L}$ (9.67-34.33) at day -1 to $63.46 \mathrm{ng} / \mathrm{L}(22.15-93.31)$ at day $12(\mathrm{P}=0.039)$ and to $89.26 \mathrm{ng} / \mathrm{L}(34.66-129.78)$ at day $22(\mathrm{P}<0.001)$. 
No differences were found in serum Hs-TnT levels: $3.00 \mathrm{ng} / \mathrm{L}$ (3.00-3.88) ng/L at day -1; $3.34 \mathrm{ng} / \mathrm{L}$ (3.009.33) $\mathrm{ng} / \mathrm{L}$ at day 12 ; and $4.26 \mathrm{ng} / \mathrm{L}$ (3.00-21.90) $\mathrm{ng} / \mathrm{L}$ at day 22. However, there was a significant widening in the amplitude distribution of the values from day -1 to day $22(P<0.001)$. Figure 3 reports the trend for the cardiac biomarker concentrations.

A fairly positive correlation was found between NT-proBNP and Hs-TnT levels ( $r=0.44, \mathrm{P}=0.022)$.

When NT-proBNP concentrations were corrected for $\triangle \mathrm{PV} \%$ changes, the significance was kept but their levels were found to increase: day -1 vs. day $12(P<0.001)$; day -1 vs. day $22(P<0.001)$ and day 12 vs. day $22(P=0.008)$. The $P V \%$ change did not affect the TnT concentrations.
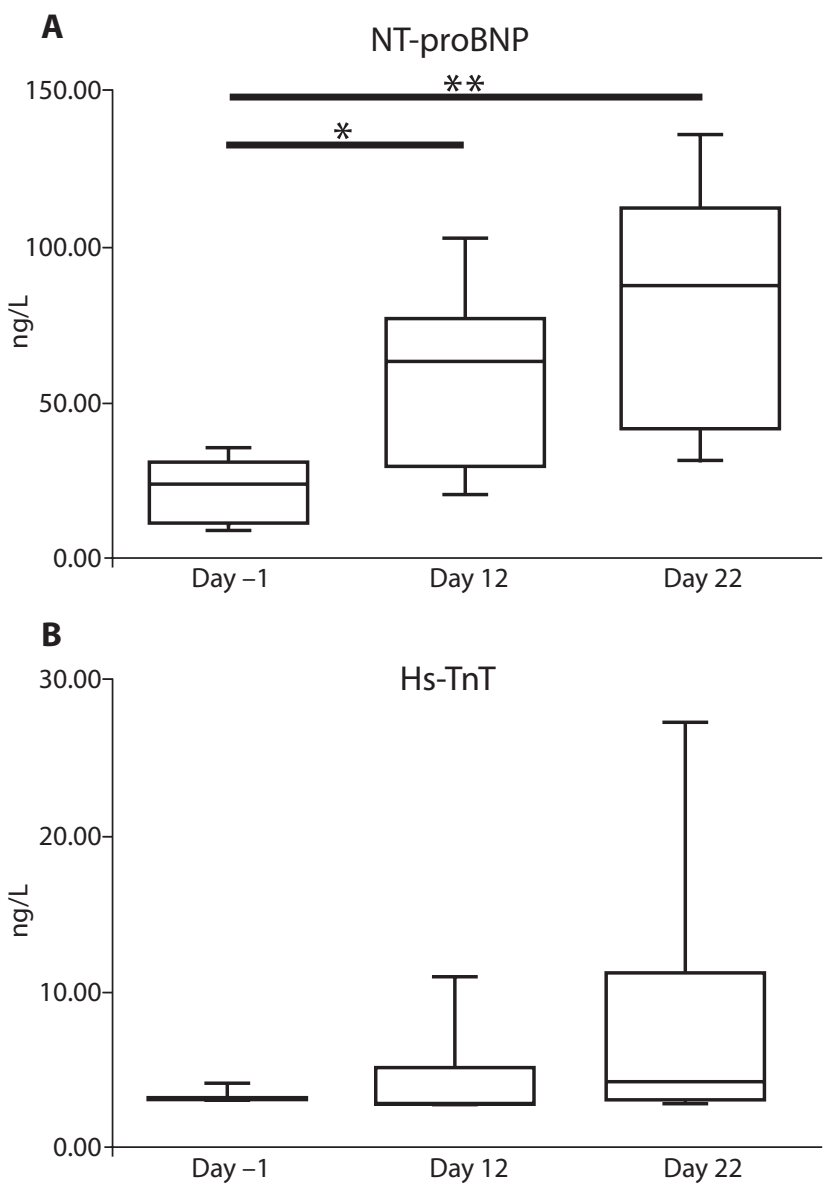

Figure 3. Changes in serum cardiac markers during the race. The graph shows the trend for concentrations of NT-proBNP (panel A) and Hs-TnT (panel B). * $\mathrm{P}<0.05,{ }^{*}$ : $\mathrm{P}<0.001$.
A moderately significant negative correlation was also found between BMI and NT-proBNP concentration $(r=-0.54, P=0.004)$ but not between $\mathrm{BMI}$ and TnT concentration ( $r=-0.25, P=0.199)$.

No correlations were found between either biomarker concentration and PV\%; however, while there was a fairly significantly correlation between the percentage variation in NT-proBNP concentration and the $\triangle P V \%$ across the time-points $(r=0.47$, $P=0.015)$, no such correlation was seen for TnT concentration $(r=-0.08, P=0.694)$.

There was a significant and moderately negative correlation between NT-proBNP and heart rate $(r=$ $-0.51, P=0.006)$ but not between heart rate and $\operatorname{TnT}(r=-0.19, P=0.348)$.

NT-proBNP concentrations fairly correlated with systolic pressure $(r=0.39, P=0.046)$ but not with diastolic pressure $(r=0.32, P=0.081)$.

Interestingly, there was a significant correlation between NT-proBNP and net energy expenditure $(r=0.70, P<0.001)$ and a fairly significant correlation with $\operatorname{TnT}(r=0.39, P=0.013)$.

\section{Discussion}

NT-proBNP levels increased significantly during the 3-weeks stage race and were accompanied by a widening of the standard deviation, with high inter-individual variability, particularly after heavy and strenuous endurance exercise in these athletes, as observed previously $(3,7,22)$. Increased NTproBNP may be interpreted as a possible sign of transitory heart damage and a potential risk for both professional and recreational athletes alike (23). Reports of abnormally high post-race NTproBNP concentrations (182 $\mathrm{ng} / \mathrm{L}$ ) in non-professional marathoners highlight the potentially dangerous effects of endurance performance on the heart. However, the starting median one study found in non-professional athletes was already high (106 ng/L), inevitably affecting interpretation of the data (7). Resting NT-proBNP values in marathoners (28.8 and $44 \mathrm{ng} / \mathrm{L})(5,22)$, mountain marathoners (39.7 $\mathrm{ng} / \mathrm{L})(4)$ and the pre-race values in our cyclists were within the reference limits for the general population (24). These cyclists were well- 
trained professional athletes capable of withstanding high, specific workloads; therefore, despite continuous stimulation of heart wall, the stable, low values could be considered a typical feature of their physiological condition.

Our data are in line with those obtained in 20 endurance athletes (10 triathletes, 5 cyclists, 5 marathoners) (median concentration of $24.7 \mathrm{ng} / \mathrm{L}$ versus $28.9 \mathrm{ng} / \mathrm{L}$ in the controls) (2). Low NT-proBNP concentrations were also found in 50 professional cyclists (mean of $23.6 \mathrm{ng} / \mathrm{L}$ versus $36.3 \mathrm{ng} / \mathrm{L}$ in 35 sedentary subjects) (10).

Strenuous physical exercise increases the production of NT-proBNP in professional athletes. The end-race values we found were similar to those reported after a mountain marathon (median of 97.6 ng/L) (9) and a marathon (150.2 ng/L) (3). Such increases could result from the repeated release of NT-proBNP which, because of continuous and stressful exercise, is not completely recovered. Following a bout of 3-hour long exercise in trained subjects, NT-proBNP increased from 19 to $49 \mathrm{ng} / \mathrm{L}$ and then fell to $38 \mathrm{ng} / \mathrm{L}$ within 3 hours after the end of the exercise (2). In the present study, the release of NT-proBNP may have been constant during the race: gradual recovery was possible during the easier first part but was hindered by the much more difficult second part (differences in elevation of $21,952 \mathrm{~m}$ versus $40,313 \mathrm{~m}$ ). This is confirmed by the strong correlation between the trends for NTproBNP concentration and energy expenditure as a measure of physical effort.

No data exist about NT-proBNP behaviour in professional cyclists. One study involving 29 recreational cyclists during the 2004 Ötztal Radmarathon evaluated NT-pro-BNP. NT-proBNP significantly increased from $28 \pm 21$ to $278 \pm 152 \mathrm{ng} / \mathrm{L}$ immediately after the race, and then decreased the following day before returning to baseline values 1 week later (25). Differences between professional and non-professional athletes aside, the dramatic increase in the biomarker in these recreational athletes is evident. Because of its typical release kinetics, the authors attributed the decrease in NT-proBNP to an adequate volume regulatory response of a hemodynamically stressed heart to prolonged strenuous exercise.
A bimodal increase in NT-proBNP was reported in 10 trained male cyclists (age, $40.0 \pm 4.5$ years) who simulated the 2007 Tour de France. After the third stage of the race simulation, NT-proBNP increased up to $200 \mathrm{ng} / \mathrm{L}$, returned to $50 \mathrm{ng} / \mathrm{L}$ at stage 12 , before increasing again to about $250 \mathrm{ng} / \mathrm{L}$ at stage 17 (26). It should be remarked that the rise in NTproBNP was linked to impaired diastolic function causing residual diastolic ventricular filling. Systolic function, represented primarily by global and segmental ejection fractions, was not affected until about stage 9, after which the values stabilized or rose slightly. A direct connection with cardiac biomarkers was not observed (26). In our sample of professional cyclists, although cardiac function did not change during the race, a mild but significant correlation was found between NT-proBNP and both heart rate (negatively) and systolic pressure (positively).

Increased NT-proBNP during and after exercise is linked to the growth-regulating properties of BNP, which regulates myocardial adaptation in healthy athletes (2) and is physiologically induced by systemic inflammatory cytokines (11) rather than being a clear and undoubted sign of heart damage, which rarely occurs (27).

Troponin release after exercise, especially after endurance events, has been reported mostly in runners and marathoners. Exercise-induced cTnT release was apparent in almost half of endurance athletes according to a meta-analysis of 26 relevant studies (1120 cases) (28).

The interpretation of elevated Tns is undefined. Current guidelines for the identification of acute myocardial infarction are based on positive serum troponin values. However, a number of studies have reported positive values for CTnT levels in asymptomatic, healthy subjects after endurance exercise, suggesting that positive cTnT values can result after strenuous exercise (29). The introduction in laboratory routine of highly sensitive assays for cTnT has increased the possibility of their misclassification: while these tests have higher analytical sensitivity (i.e., low limit of detection) and a higher negative predictive value of troponin, their clinical specificity is lower (12). The reference population where the $99^{\text {th }}$ percentile limit of the refer- 
ence value distribution (99th URL) obtained with assays having a coefficient of variation $<10 \%$ at those levels must be accurately selected for obtaining clinically valid data (30).

There are few studies on Hs-TnT levels in athletes. After a marathon, Hs-TnT was higher than the URL $(0.016 \mu \mathrm{g} / \mathrm{L})$ in $86 \%$ of 70 male and 15 female amateur runners (age range, 45-49 years) (31). In another study on 10 male amateur marathoners with a similar age range, Hs-TnT was higher than the URL $(0.012 \mu \mathrm{g} / \mathrm{L})$ after an ultramarathon of $216 \mathrm{~km}$, but unexpectedly, the percentage of positivity immediately after the race was lower than that described after a classical marathon (40\%) (32).

A similar positive percentage after a classical marathon was, however, reported in amateur male runners by using the lowest URL $(0.010 \mu \mathrm{g} / \mathrm{L} ; 43 \%)$ (33). After a marathon, Hs-TnT kinetics revealed a peak immediately after the race that decreased rapidly to pre-test values within $72 \mathrm{~h}$ (median, $31.07 \mu \mathrm{g} / \mathrm{L}$ and $3.61 \mu \mathrm{g} / \mathrm{L}$, respectively) in 102 healthy men (mean age, $42 \pm 9$ years). The authors stated that kinetics with a sharp peak indicate that cardiac necrosis during marathon running, though seemingly very unlikely, are a function of altered myocyte metabolism (34).

Data on professional cyclists during prolonged performances or by using Hs-cTnT are lacking. One study using a second-generation cTnl assay on trained male cyclists who simulated the 2007 Tour de France found a 30\% increase in cTnl after the first stage. The positive value percentage decreased until stage 12 , when $50 \%$ of the sample showed positive values, and then peaked at stage $15(60 \%)$, before the positive values returned to $30 \%$ at stages 17 and 18 (26). Positive values were measured in 6 out of 10 cyclists but were not homogeneously distributed over time, with some subjects showing only two positive values during the stage race, whilst others showed five or more positive values. The highest number of positive values was recorded during the stages of the third week.

While troponin release during a 3-weeks stage race does not appear to be predictable, there is a rough relationship between its release and the de- mand and technical difficulties of race stages. Our data confirm this finding: while only one subject had detectable, but within range, TnT concentrations at pre-race, we found only one positive value $(>0.010 \mu \mathrm{g} / \mathrm{L})$ at half race and 3 out of $11(23 \%)$ at the end of the race.

A study involving professional cyclists during a Giro d'Italia was performed using a first-generation cTnT assay. In 25 athletes from five different teams, blood drawings were performed before the race and at 7, 14, and 21 days. Participant withdrawals from the race and dropouts from the study reduced the final study population from 17 to 10 subjects. TnT was detected in 5 athletes, repeatedly in some cases, in a total of 10 samples out of 64 , but without exceeding the cut-off for assuming myocardial damage (18). In general, we can assume that we observed similar results. However, the specificity of the two assays is completely different, since skeletal troponin might have interfered with the results obtained from the old assay. Moreover, a stable haematocrit was reported in that study (18), while plasma volume and consequently haemodilution was observed in ours.

The data we obtained in professional cyclists during a 3-weeks stage race hold particular interest and fill a gap in the current literature on cardiac markers during and after endurance exercise.

This is the first study to describe the behaviour of cardiac stress markers in professional cyclists during a 21-days stage race. The main finding is the evidence for an association between changes in cardiac biomarker concentrations (NT-proBNP and $\mathrm{TnT}$ ) and net energy expenditure, and indirectly the metabolic effort spent during prolonged endurance performance.

The main limitation of our study resides in the small sample size. The number of subjects was dictated by belonging to the team, collaborating in the study, other than being derived from a sample size calculation. Moreover, NSAIDs and antibiotic therapy was administered in three cases. Even if the treatment was specific for respiratory tract infection and brief, a possible effect of NSAIDs on cardiac biomarkers cannot be ruled out. In conclusion, elevated NT-proBNP during a 3-weeks cycling 
stage race could be interpreted as an adaptation of the heart in response to stimulation by a very high workload and heavy and stressful exercise, as demonstrated by the increased energy expenditure. The link between increased NT-proBNP and altered cardiac function, and the recovery of diastolic impairment described in prolonged cycling in particular, needs to be further explored.

Also, elevated troponin concentrations may result from the extreme effort involved during such an endurance sport event. Although the concentrations of both biomarkers fell within the physiological range, with only a few subjects exceeding the upper range limits, the possible event of transient

\section{References}

1. Mottram PM, Haluska BA, Marwick TH. Response of B-type natriuretic peptide to exercise in hypertensive patients with suspected diastolic heart failure: correlation with cardiac function, hemodynamics, and workload. Am Heart J 2004; 148:365-70.

2. Scharhag J, Urhausen A, Schneider G, Herrmann M, Schumacher $K$, Haschke $M$, et al. Reproducibility and clinical significance of exercise-induced increases in cardiac troponins and $\mathrm{N}$-terminal pro brain natriuretic peptide in endurance athletes. Eur J Cardiovasc Prev Rehabil 2006;13:388-97.

3. Melanson SE, Green SM, Wood MJ, Neilan TG, Lewandrowski EL. Elevation of myeloperoxidase in conjunction with cardiac-specific markers after marathon running. Am J Clin Pathol 2006;126:888-93.

4. Banfi G, Lippi G, Susta D, Barassi A, D'Eril GM, Dogliotti G, et al. NT-proBNP concentrations in mountain marathoners. J Strength Cond Res 2010;24:1369-72.

5. Lippi G, Schena F, Salvagno GL, Montagnana M, Gelati M, Tarperi $C$, et al. Influence of a half-marathon run on NTproBNP and troponin T. Clin Lab 2008;54:251-4.

6. Banfi G, D'Eril GM, Barassi A, Lippi G. N-terminal proB-type natriuretic peptide (NT-proBNP) concentrations in elite rugby players at rest and after active and passive recovery following strenuous training sessions. Clin Chem Lab Med 2008;46:247-9.

7. Neilan TG, Januzzi JL, Lee-Lewandrowski E, Ton-Nu TT, Yoerger DM, Jassal DS, et al. Myocardial injury and ventricular dysfunction related to training levels among nonelite participants in the Boston marathon. Circulation 2006; 114:2325-33.

8. Mair J, Hammerer-Lercher A, Puschendorf B. The impact of cardiac natriuretic peptide determination on the diagnosis and management of heart failure. Clin Chem Lab Med 2001;39:571-88.

9. Banfi G, Migliorini S, Dolci A, Noseda M, Scapellato L, Franzini C. B-type natriuretic peptide in athletes performing an Olympic triathlon. J Sports Med Phys Fitness 2005;45:529-31. overload, which must be recovered before exercise is resumed, poses a health concern in individuals with occult heart disease.

\section{Acknowledgements}

We are grateful to the Liquigas-Cannondale procycling team for their participation and assistance in logistics during the study. We wish to thank Dr Antonino Coco for performing the blood drawings at day 12 . We are also indebted with Mr Kenneth Britsch for language editing and with Dr Alessandra Grotta for her help in statistical revision.

\section{Potential conflict of interest}

None declared.

10. Lippi G, Salvagno GL, Montagnana M, Schena F, Ballestrieri F, Guidi GC. Influence of physical exercise and relationship with biochemical variables of NT-pro-brain natriuretic peptide and ischemia modified albumin. Clin Chim Acta 2006;367:175-80.

11. McLachlan C, Mossop P. Are elevations of N-terminal probrain natriuretic peptide in endurance athletes after prolonged strenuous exercise due to systemic inflammatory cytokines? Am Heart J 2006;152:e1.

12. Lippi G, Cervellin G, Banfi G, Plebani M. Cardiac troponins and physical exercise. It's time to make a point. Biochem Med 2011;21:55-62.

13. Plebani M, Zaninotto M. Cardiac troponins: what we knew, what we know - where are we now? Clin Chem Lab Med 2009;47:1165-6.

14. Giannoni A, Giovannini S, Clerico A. Measurement of circulating concentrations of cardiac troponin I and T in healthy subjects: a tool for monitoring myocardial tissue renewal? Clin Chem Lab Med 2009;47:1167-77.

15. Hickman PE, Potter JM, Aroney C, Koerbin G, Southcott E, $W u A H$, et al. Cardiac troponin may be released by ischemia alone, without necrosis. Clin Chim Acta 2010;411:318-23.

16. Lippi G, Banfi G. Exercise-related increase of cardiac troponin release in sports: An apparent paradox finally elucidated? Clin Chim Acta 2010;411:610-1.

17. Serrano-Ostariz E, Legaz-Arrese A, Terreros-Blanco JL, LopezRamon M, Cremades-Arroyos D, Carranza-Garcia LE, et al. Cardiac biomarkers and exercise duration and intensity during a cycle-touring event. Clin J Sport Med 2009;19:293-9.

18. Bonetti A, Tirelli F, Albertini R, Monica C, Monica M, Tredici G. Serum cardiac troponin $T$ after repeated endurance exercise events. Int J Sports Med 1996;17:259-62.

19. Union Cycliste Internationale. UCI Anti-doping procedural guidelines 7.0. Storage and Transport of samples. Available at: http://www.uci.ch/Modules/BUILTIN/getObject.asp?Me nuld $=$ MTI1NzE\&ObjTypeCode=FILE\&type $=$ FILE\&id=NDA3 MTk\&Langld=1. Accessed December 2011. 
20. World Anti-doping Agency. Requirements for passport operation from international standard for testing and international standard for laboratories. Available at: http://www.wada-ama.org/Documents/Resources/Guidelines/WADA_ABP_ OperatingGuidelines_EN_2.1.pdf. Accessed October 2011.

21. Dill DB, Costill DL. Calculation of percentage changes in volumes of blood, plasma, and red cells in dehydration. J Appl Physiol 1974;37:247-8.

22. Herrmann $M$, Scharhag J, Miclea M, Urhausen A, Herrmann W, Kindermann W. Post-race kinetics of cardiac troponin $T$ and $\mathrm{I}$ and $\mathrm{N}$-terminal pro-brain natriuretic peptide in marathon runners. Clin Chem 2003;49:831-4.

23. Thompson PD, Apple FS, Wu A. Marathoner's heart? CircuIation 2006;114:2306-8.

24. Hess $G$, Runkel S, Zdunek $D$, Hitzler WE. Reference interval determination for $N$-terminal-B-type natriuretic peptide (NT-proBNP): a study in blood donors. Clin Chim Acta 2005;360:187-93.

25. Neumayr G, Pfister R, Mitterbauer G, Eibl G, Hoertnagl H. Effect of competitive marathon cycling on plasma N-terminal pro-brain natriuretic peptide and cardiac troponin $T$ in healthy recreational cyclists. Am J Cardiol 2005;96:732-5.

26. Williams K, Gregson W, Robertson C, Datson N, Whyte G, Murrell $C$, et al. Alterations in left ventricular function and cardiac biomarkers as a consequence of repetitive endurance cycling. Eur J Sport Sci 2009;9:97-105.

27. Pedoe DST. Marathon cardiac deaths - The London experience. Sports Medicine 2007;37:448-50.
28. Shave R, George KP, Atkinson G, Hart E, Middleton N, Whyte $G$, et al. Exercise-induced cardiac troponin T release: a meta-analysis. Med Sci Sports Exerc 2007;39:2099-106.

29. Eijsvogels TM, Shave R, van Dijk A, Hopman MT, Thijssen $D H$. Exercise-induced cardiac troponin release: real-life clinical confusion. Curr Med Chem 2011;18:3457-61.

30. Collinson PO, Heung YM, Gaze D, Boa F, Senior R, Christenson $R$, et al. Influence of population selection on the 99th percentile reference value for cardiac troponin assays. Clin Chem 2012;58:219-25.

31. Mingels A, Jacobs L, Michielsen E, Swaanenburg J, Wodzig $W$, van Dieijen-Visser M. Reference population and marathon runner sera assessed by highly sensitive cardiac troponin T and commercial cardiac troponin T and I assays. Clin Chem 2009;55:101-8.

32. Giannitsis E, Roth HJ, Leithauser RM, Scherhag J, Beneke $R$, Katus HA. New highly sensitivity assay used to measure cardiac troponin $T$ concentration changes during a continuous 216-km marathon. Clin Chem 2009;55:590-2.

33. Knebel F, Schimke I, Schroeckh S, Peters H, Eddicks S, Schattke $S$, et al. Myocardial function in older male amateur marathon runners: assessment by tissue Doppler echocardiography, speckle tracking, and cardiac biomarkers. J Am Soc Echocardiogr 2009;22:803-9.

34. Scherr J, Braun S, Schuster T, Hartmann C, Moehlenkamp S, Wolfarth $B$, et al. 72-h kinetics of high-sensitive troponin $T$ and inflammatory markers after marathon. Med Sci Sports Exerc 2011;43:1819-27.

\section{Srčani indeksi, biološki biljezi srčanog oštećenja i potrošnja energije kod profesionalnih biciklista tijekom trotjedne etapne utrke Giro d'Italia}

\section{Sažetak}

Uvod: Ispitivanje srčanog odgovora na napornu i kontinuiranu tjelovježbu ključno je za razumijevanje fiziologije izdržljivosti. N-terminalni moždani natrijuretski peptid (engl. N-terminal pro-brain natriuretic peptide, NT-proBNP) mogući je biljeg za praćenje opterećenja stjenke miokarda, a troponini (TnT i Tnl) su u širokoj primjeni kod dijagnosticiranja srčane ishemije i infarkta miokarda. Uslijed naporne tjelovježbe mogu se razviti prolazna ishemija, opterećenje miokarda te dijastolička disfunkcija lijeve klijetke što potiče povećano stvaranje oba biološka biljega. Mjerili smo promijene koncentracija NT-proBNP i TnT kod vrhunskih biciklista tijekom trotjedne etapne utrke, kao primjera naporne tjelovježbe.

Materijali i metode: Ispitivanu je populaciju činilo 9 profesionalnih biciklista koji su sudjelovali na utrci Giro d'Italia. Prijeanalitička i analitička faza provedene su savjesno i pridržavajući se službenih preporuka. Bilježeni su antropometrički podaci, potrošnja energije i srčani indeksi (otkucaji srca, sistolički i dijastolički krvni tlak). Krv je sakupljena jedan dan prije utrke (dan -1), 12. i 22. dan utrke; analizom su utvrđene koncentracije NTproBNP i srčanog troponina T visoke osjetljivosti (engl. highly sensitive-troponin T, Hs-TnT) te je napravljena korekcija promjena volumena plazme.

Rezultati: Tijekom utrke se kod ispitanika snizio indeks tjelesne mase, a potrošnja energije se povećala za $52 \%$. Koncentracije NT-proBNP su porasle [dan -1: 23,52 ng/L (9,67-34,33); 12. dan: 63,46 ng/L (22,15-93,31); $\mathrm{P}=0,039 ; 22$. dan: 89,26 ng/L (34,66-129,78) prema danu $-1 ; \mathrm{P}<0,001]$ i bile u korelaciji s otkucajima srca $(r=-0,51 ; P=0,006)$, sistoličkim krvnim tlakom $(r=0,39 ; P=0,046)$ i potrošnjom energije $(r=0,70 ; P<$ 0,001). Koncentracije TnT nisu varirale, no primijećena je proširena distribucija amplitude InT.

Zaključak: Povećanja koncentracije NT-proBNP bila su u korelaciji s višom potrošnjom energije tijekom trotjedne biciklističke etapne utrke što bi moglo ukazivati na opterećenje miokarda.

Ključne riječi: N-terminalni moždani natrijuretski peptid; troponin T; fizička izdržljivost; potrošnja energije 